\title{
Veiled Muslim women's responses to experiences of gendered Islamophobia in the UK
}

\begin{abstract}
In a post-9/11 climate, Islamophobia has increased significantly in the UK and elsewhere in the West. ISIS-inspired terrorist attacks in the UK as well as in France, Belgium, Germany and more recently in Sri Lanka have triggered an increase in verbal and physical attacks against Muslims. Drawing on intersectionality (as a nexus of identities that work together to render certain individuals as 'ideal' targets to attack), veiled Muslim women are likely to experience gendered Islamophobia in the cyber world but also in 'real' life due to the intersections between their 'visible' Muslim identity and gender performance. In the British context, although Islamophobia is recorded as a hate crime nationally, and misogyny is recorded as a hate crime locally in some police forces, veiled Muslim women are unlikely to report their experiences to the police. Drawing on qualitative interviews with Muslim women who wear the niqab (face veil), the purpose of this paper is to examine the ways in which they respond to experiences of gendered Islamophobia as well as their reasons for not reporting their experiences to the police.
\end{abstract}

Keywords: Gender, Hate Crime, Misogyny, Muslim women, Veil

\section{Introduction}

Following the terrorist attacks of $9 / 11$ and 7/7, and more recently the ISIS-inspired attacks in the UK, France, Belgium, Germany and Sri Lanka, the religion of Islam is associated with violence, religious fundamentalism, gender inequality and the global 'war on terror'. The wearing of the niqab (face veil) is perceived as the key visual symbol of Islam in the West. Typically, media discourses about Islamist extremism are illustrated by the image of a Muslim woman in niqab. The wearing of the niqab is also seen as a 'threat' to notions of integration and national cohesion as well as a visual embodiment of gender oppression and gender inequality. According to Perry (2014), the controlling images of veiled Muslim women render them especially attractive and available targets for hate crime. The research literature shows that Islamophobia is highly gendered (Tell MAMA, 2017; Author, 2016; 2014; Allen, Isakjee and Young, 2013; Githens-Mazer and Lambert, 2010; Wing and Smith, 2006). Drawing on intersectionality (as a nexus of identities that work together to render certain individuals as 'ideal' targets to attack), veiled Muslim women are more likely to suffer hate crime due to intersections between their 'visible' Muslim identity and gender performance, coupled with other aspects of their perceived identity such as race, disability and age.

Nationally and internationally, the notion of 'hate crime' is characterised by the incitement of hatred based upon hostility towards the victim's identity. In the UK, legislation is centered around the 'five strands' of race or ethnicity, religion, sexual orientation, transgender identity and disability (College of Policing, 2014). From this perspective, Islamophobia falls into the category of 'religiously motivated hate 
crime'. However, it is important to note that the suffix 'phobia' is a contested term. Rather, Islamophobia has been defined as 'anti-Muslim racism' (Runnymede Trust Report, 2017). Along similar lines, the All Party Parliamentary Group on British Muslims (2018: 11) has offered the following definition: "Islamophobia is rooted in racism, and is a type of racism that targets expressions of Muslimness or perceived Muslimness". Therefore, in this paper Islamophobia is understood as a form of racism towards actual and perceived Muslims (Author, 2018).

At the time of writing this paper, misogyny is not recorded as a hate crime nationally. In 2016, Nottinghamshire Police became the first force in the country to record harassment of women as a hate crime in order to tackle misogyny and street harassment. Since then, other police forces (namely, North Yorkshire Police and Leicestershire Police) have agreed to begin recording misogyny as a hate crime and a number of other forces are looking into this. Understanding the victimisation of veiled Muslim women as a form of gendered Islamophobia means that they are locked in a circle of targeted victimisation due to intersections between their 'visible' Muslim identity and gender performance. Accordingly, there are unique emotional, psychological and behavioural consequences for veiled Muslim women as actual and potential victims of gendered Islamophobia. Everyday experiences of both explicit and subtle manifestations of Islamophobic and misogynistic harassment produce, inter alia, feelings of inferiority, loss of confidence and self-esteem, depression, guilt and self-blame. However, the extent to which these effects determine veiled Muslim women's lived experiences arises out of a complex interaction between the nature of this victimisation, victims' coping mechanisms as well as the amount of support that they receive. Drawing on qualitative interviews with Muslim women who wear the niqab, this paper examines the ways in which they respond to experiences of gendered Islamophobia as well as their reasons for not reporting their experiences to the police.

\section{Literature Review}

Understanding the stereotypes associated with veiled Muslim women

Gendered Islamophobia is associated with the negative images and stereotypes of the niqab as a symbol of gender oppression, self-segregation and Islamist terrorism. Bullock and Jafri (2002: 36) highlight three 'personas' that Muslim women occupy in the popular imagination, and thus define what Muslim women 'are supposed to be and do': the first is the 'harem belly-dancer character,' the mysterious and sexualized woman of the 'Orient'; the second is 'the oppressed Muslim woman', and, finally, there is the 'militant Muslim woman'. From this perspective, veiled Muslim women are constructed as racialised, exotic 'Others' who do not fit the Western ideal of womanhood (Perry, 2014). The wearing of the niqab signals Muslim women as docile, oppressed, submissive and passive. As such, the wearing of the niqab is understood as an oppressive and subordinating practice, which is not 'welcome' in the West (Author, 2012). Referring to Muslim women who wear the hijab (headscarf), Mahmud and Swami (2010) found that they were considered unattractive and less intelligent, whilst Unkelbach et al. $(2008,2009)$ found that they were subjected to 
more aggressive behaviour in a shooter bias paradigm than non-hijabi targets. That said, it is also important to recognise that Islamophobia does not occur in a vacuum. The political context that gives oxygen to Islamophobia to reproduce itself is relevant here. In August 2018, former foreign secretary Boris Johnson compared Muslim women in niqab to 'letterboxes' and 'bank robbers' (Elgot, 2018). The then Prime Minister Theresa May urged Johnson to apologise for these comments after he defied an order to do so by Tory chiefs.

While the wearing of the niqab is taken as a symbol of gender inequality and oppression, it is also perceived as a sign of Islamist terrorism. Even though Muslim women are stereotypically seen as being oppressed and Muslim men are stereotypically seen as being aggressive and violent, it should be noted that Muslim women are not free from the common Muslim stereotypes as Muslims in general are portrayed as evil, barbaric, backwards, terrorists, religious fundamentalists and uncivilised (Cole and Ahmadi, 2003; Haddad, 2007). As Perry (2014) points out, if veiled Muslim women are not characterised as exotic or oppressed, they are represented as dangerous and threatening; this is fuelled by the controlling image of 'Muslim as terrorist.' To this end, veiled Muslim women are represented as 'agents' of terrorism or as the tools of Islamist terrorism aiming to infiltrate the West (Jiwani, 2005). As such, Muslim women are not seen as 'real' women or mothers like Western women; rather, they are seen as 'mothers of suicide bombers' (Perry, 2014). Specifically, Muslim women who wear the niqab are seen as 'terrorist bodies' on the basis that their face is covered and to this end, the veil could be used as a camouflage for a terrorist (Author, 2014).

Finally, veiled Muslim women are also seen as 'easy', 'weak' targets to attack because of the visibility of their Muslim identity. Indeed, it is well established in the literature that there is a significant relationship between being visible as a Muslim and experiencing Islamophobia (Allen, 2010; Author, 2014). As Garner and Selod (2015) note, if the markers of Islam are absent, 'passing' as a non-Muslim is possible for those who do not 'look like' a Muslim. As such, being visually identifiable as a Muslim has been found to be the most powerful antecedent to negative behaviours against Muslims (Allen and Nielson, 2002). Taken in isolation or collectively, these stereotypes incite hostility, abuse and harassment towards veiled Muslim women as a means of responding to the multiple 'threats' of the niqab as a symbol of gender oppression, self-segregation and Islamist terrorism.

\section{Intersectionality}

Through the lens of intersectionality, the targeted victimisation of veiled Muslim women can be understood as 'gendered Islamophobia' on the basis that they are targeted due to the intersections between their 'visible' Muslim identity and gender performance. 
Intersectionality is a sociological theory that asserts that social identities are not merely independent or additive; rather multiple social identities converge to create unique experiences of oppression (Hill Collins, 1990; Crenshaw, 1989). American critical race scholar Kimberlé Crenshaw (1989, 1991) coined the term 'intersectionality' as a way of conceptualising identity, particularly in terms of underscoring the multidimensionality of marginalised individuals' lived experiences. Crenshaw (1989) used the metaphor of intersecting roads to describe and explain the ways in which racial and gender discrimination intersect. Specifically, Crenshaw (1989: 149) used the following analogy to concretise the concept:

Consider an analogy to traffic in an intersection, coming and going in all four directions. Discrimination, like traffic through an intersection, may flow in one direction, and it may flow in another. If an accident happens in an intersection, it can be caused by cars traveling from any number of directions and, sometimes, from all of them. Similarly, if a Black woman is harmed because she is in an intersection, her injury could result from sex discrimination or race discrimination ... But it is not always easy to reconstruct an accident: Sometimes the skid marks and the injuries simply indicate that they occurred simultaneously, frustrating efforts to determine which driver caused the harm.

In her work on discrimination against Black women, Crenshaw (1989) argues that they are discriminated against in ways that often do not fit neatly within the legal categories of either 'racism' or 'sexism' - but as a combination of both racism and sexism. As such, intersectionality rejects the single-axis framework (which maintains a focus on either race or gender) on the basis that this approach fails to consider how Black women are vulnerable to both grounds of discrimination. Rather, intersectionality analyses 'the various ways in which race and gender interact to shape the multiple dimensions of Black women's experiences' (Crenshaw, 1991: 1244). The road metaphor quoted above describes the way in which a minority group "navigates a main crossing, whereby the racism road crosses with the streets of colonialism and patriarchy, and 'crashes' occur at the intersections. Where the roads intersect, there is a double, triple, multiple, and many-layered blanket of oppression" (Dhamoon, 2011: 231).

McCall (2005: 1771) stresses that intersectionality has become the 'gold standard' multidisciplinary approach for analysing participants' experiences of identity and oppression, calling it 'the most important theoretical contribution that women's studies, in conjunction with related fields, has made so far". Indeed, Crenshaw's formulation of intersectionality has been enormously significant, as it further opened up a conceptual space through which to identify how various oppressions work together to produce something unique and distinct from any one form of discrimination standing alone (Dhamoon, 2011). In the context of the present study, intersectionality can be understood as a nexus of identities that work together to 
render Muslim women as 'ideal' targets to attack due to their religion and gender performance.

\section{Methodology}

The research took the form of a qualitative study based on semi-structured interviews with niqab-wearing Muslim women who had experienced Islamophobia in public. Specifically, the study included 60 individual interviews and 20 focus groups with veiled Muslim women in Leicester between 2011 and 2012. Participation in the study was voluntary. In light of its diverse mix of cultures and faiths, Leicester is commonly depicted as the reflection of a modern, vibrant, multi-cultural city. As one of the most diverse cities in the UK, Leicester offers the ideal site in which to conduct this study. A key reason for deciding to focus on the city of Leicester is its high Muslim population. In particular, Leicester is home to a large number of Muslim women who wear the niqab. Prospective participants were identified through local Muslim organisations including mosques, Muslim schools and Islamic centres, as well as local Muslim university student societies, and Muslim women's groups. Participants unaffiliated to any local Muslim organisations or groups were also recruited through snowball sampling.

All interviews were digitally recorded, transcribed verbatim and then analysed using Grounded Theory (Glaser and Strauss, 1967). Grounded Theory is defined as 'the discovery of theory from data - systematically obtained and analysed in social research' (Glaser and Strauss, 1967: 1). Within this framework, the methodology involved constant comparative analysis and theoretical sampling (Glaser and Strauss, 1967). Constant comparative analysis means that data collection and analysis are parallel. As such, the author did not wait until data collection was completed in order to analyse the data; rather the author used an iterative process of concurrent data collection and analysis. Theoretical sampling is 'The process of collecting data for comparative analysis' (Glaser and Strauss, 1967: 9). Within the Grounded Theory framework, theory generated from the data guided subsequent data collection; in other words, insight from initial data collection and analysis led to subsequent data collection and analysis (Cho and Lee, 2014). Data analysis followed Charmaz's (2006) coding process, which involves three stages: initial (open) coding, focused coding, and theoretical coding. NVivo 9, which is a qualitative analysis software package, was used to code the data. Grounded Theory, which is based on an inductive approach (eg codes, categories and themes are directly drawn from the data) involves developing a 'story' that emerges from the data. Within this framework, participants' responses are construed as evidence of what they think and feel and how they interpret the social world (Glaser, 1992). In this case, verbatim transcripts are essential for Grounded Theory analysis as they capture information in participants' own words, phrases and expressions as well as providing 'rich' detail. In the following quotes, pseudonyms are used in order to protect participants' identity. 


\section{Nature of the problem}

Throughout individual and focus group interviews, participants described incidents of attempted and/or actual physical assaults (including taking the veil off), pushing, shoving, being spat at and even incidents where passing vehicles had attempted to run them over. They also described incidents where people on the street or from moving cars had thrown eggs, stones, alcohol, water bombs, bottles, take-away food and rubbish at them. Additionally, verbal abuse from strangers in public (including streets, parks, shopping centres and public transport) was a common experience amongst participants. In some cases, participants experienced verbal and non-verbal sexual harassment in public spaces. They reported that unknown men on the street made sexual comments and/or sexual noises at them (often accompanied by sexual gestures). Perpetrators often asked them questions about their sexual life and/or their sexuality. Also, participants were subjected to wolf whistling, catcalling and sexist jokes. Participants also reported experiencing abuse, hostility and intimidation on social networking sites such as Facebook and Twitter as well as blogs and chat rooms.

Underlying these incidents of intimidation, violence and abuse was a clear sense of Islamophobic and misogynistic attitudes, and this was made apparent through the language used by the perpetrators that signified their motivations for the attack. For example, participants were subjected to swearing such as 'Muslim bitch', 'Muslim whore' and 'Fucking freak', which indicated that that they were targeted for both their Muslim identity and gender performance. Moreover, participants reported being used as a form of 'entertainment'. For example, they were called names such as 'Ninja', 'Catwoman', 'Batman', 'Darth Vader', 'Ghost woman', 'Bin bag', 'Letterbox', 'Postbox', 'Witch' and 'Walking Coffin'. Also, participants had been called names such as 'Muslim terrorists', 'Muslim bombers' and 'Suicide bombers', which indicated perpetrators' perceptions of veiled Muslim women as a security or terrorist 'threat'. 'Low-level' incidents such as persistent staring, being ignored and/or avoided, being laughed at, being monitored at shops and being stalked by strangers on the street were common themes which underpinned participants' accounts as they described their experiences of gendered Islamophobia in public.

These manifestations of gendered Islamophobia were not 'one-off' incidents; rather there was always the reality, the fear, and the expectation for another attack. This paints a picture of an everyday phenomenon, which can be better understood as a process rather than as incidental occurrences. In light of this, the majority of participants altered their lifestyle with the aim to reduce the risk of future attacks. Some participants mentioned 'no-go areas' where they would face an increased risk of abuse whilst others restricted their public travel to a minimum. Additional behavioural impacts included the desire to avoid leaving the house, as this provided them with immutability from being attacked in public. At the same time though, some participants reported feeling like 'prisoners in their own home'. As a last resort, several participants tried to hide their Muslim identity through removing the niqab in specific or all public places. 
Qualitative research into the experiences of Muslim women who wear the niqab has been conducted in five European countries, Belgium, Denmark, France, the Netherlands, and the UK (Brems, 2014). The data show very strong similarities such as street harassment and abuse of veiled Muslim women by strangers in public places. For example, veiled Muslim women in the Netherlands reported regularly being confronted with people who scolded, insulted or spat at them (Moors, 2009; 2014). Some women mentioned being physically threatened, with cars attempting to hit them, people throwing things at them or trying to pull off the niqab (Moors, 2009; 2014). Echoing these experiences, veiled Muslim women in the UK and France described a stream of violent insults in public places including being violently pushed, spat on, and having their veils pulled off (Boutelja, 2011).

In the present study, participants argued that the typical perpetrator was male (and unknown to them). Specifically, participants' accounts suggested that perpetrators were usually white men, aged between 16 and 25. Participants also stated that it was mainly working-class men who targeted them for street harassment. However, the profile of the perpetrators as being 'young, white, working-class men' does not tell the whole story. For example, participants argued that they were sometimes targeted by members of ethnic and racial minorities (including EU nationals) as well as from fellow Muslims. In very few cases where street harassers were female, this involved cases of verbal abuse and name calling rather than physical violence. For Davis (1994), while women can and do in fact make comments to other women, a qualitative difference exists; women's comments directed toward other women are not situated in the same place of power as are men's comments. However, they do demonstrate an interesting perception of veiled Muslim women as performing gender differently and perhaps in a way that female perpetrators do not like.

\section{Women's responses to gendered Islamophobia}

Participants' most common response was to ignore the abuse or pretend it did not happen. In this context, ignoring the abuse was a conscious coping strategy aimed at preventing further violence (Lambert and Githens-Mazer, 2010). By virtue of being physically weaker than their (predominantly) male abusers, participants often chose to 'let it go'. Although they often wanted to challenge their abuser's behaviour they decided not to react because of fear of the situation escalating. As the following quote shows, the fear of escalating violence often prevented participants from challenging their abusers.

I can't do anything against a man that's why I never answer back. If I answer back he might become violent towards me so I walk away and try to forget about it. Farhat 
It is also important to recognise that the interpretation of this victimisation as 'normal' was relevant to participants ignoring these incidents. For the majority of participants the accumulation of experiences of gendered Islamophobia had become a backdrop for everyday life. In their words, these incidents were perceived as 'part and parcel' of wearing the niqab in the UK. Consequently, the commonality of this form of victimisation had prompted several participants to either ignore it or dismiss it as 'not serious', as indicated in the following quotes.

I just brush it off my shoulders, what else can I do? At the time it hits me but then I forget about it because it has become an everyday type of thing. Yara

I don't tell my friends because I'm so used to it, it's not even something to talk about anymore. It happens all the time, so what? Aisha

However, in contrast to the majority of participants who routinely ignored, minimised or dismissed their experiences of gendered Islamophobia, others tried to challenge or retaliate against their abusers. For example, some participants were keen on challenging perpetrators, especially when they had made negative comments about their physical appearance behind the niqab.

Once somebody came up to me and said 'Have you got a really ugly face?' I said 'No, actually my face looks better than yours, it's too good for you to look at'. Don't give me crap, I'll give you crap. Aliyah

I was coming to Leicester from London and this guy goes 'You must be really ugly under there to cover your face' and I said 'Not as ugly as you are, trust me, you should be covering'. Shantaz

As I walked out of Trinity [shopping centre in Leeds] two lads said to me 'Are you that ugly that you have to cover your face? I said 'Well, if I had a face like yours I would never want to take my veil off'. Zafirah

Additionally, there were incidents where participants used humour to challenge their abusers, as indicated in the following quote.

When they call me a terrorist I say 'Yeah, I am a terrorist, do you want to see my gun?' and then they realise that I have a sense of humour and they just stare shocked by my response or they just walk away looking silly themselves. Nimah

Furthermore, some participants argued that they tried to 'stand up' to their abusers and retaliate against their behaviour in order to 'teach them a lesson'. In most cases, retaliation took the form of verbal abuse, as the following quotes demonstrate. 
I've used the F word so many times like 'What the fuck are you looking at?' To them it's very shocking because it's proper slang language. I know that Islamically it's not acceptable but I'm only human [laughs]. Jabeen

When people stare sometimes I say "Don't you know it's rude to stare?" [Interviewer: Are you not afraid that they might react?] No, nobody's really attacked me after I've answered back to them. They are more scared of us than we are scared of them. I think Islamophobia is that fear of Islam more than anything else. They fear that even if we make a comment it might lead to the whole city being blown up. Zareena

There is this assumption that Muslim women are oppressed so we will not react but I fight my own battles, I do stand up for myself. Once I lifted my veil up and stuck my two fingers up. Sabirah

As is evident from comments such as these, participants sometimes made a cutting remark or shouted abuse to the perpetrators as a form of retaliation. Moreover, in an eye-for-an-eye mentality, some participants physically defended themselves against their abusers. In a similar vein, participants in Lambert and Githens-Mazer's study (2010) stated that they felt compelled to respond directly and sometimes violently towards their attackers. In this study, participants reported that they were not confident that the police were sufficiently supportive in order to allow them to rely solely on legal responses to the daily violence and intimidation that they faced (Lambert and Githens-Mazer, 2010). As the following quotations indicate, retaliation in the form of physical violence was sometimes perceived to be the only 'appropriate' response.

If they spit at me I spit back at them, spiting is at another level. Jabeen

I was pregnant with my daughter and a woman pushed her trolley in a supermarket in Coventry towards my belly and that's one incident when I snapped and I hit her. I don't want to act like that because that's not the way we are taught to behave in Islam but sometimes I feel I have to. Dearbhla

I was in Norway at the airport and my mum and sisters walk really slowly, they take the piss, I am the leader of the group. There was this Jewish man who came up to me, he pushed me and shouted 'I hate Muslims'. I punched him, I am really aggressive, I can really defend myself, you know. Hakimah

It appears from the above analysis that not all veiled Muslim women accept gendered Islamophobia as a normative aspect of their lives. Clearly, some participants were not 
afraid to confront their abusers, challenge their behaviour and even retaliate, both verbally and physically. This helps to deconstruct the homogeneity of this group of women, which is often assumed by those targeting these individuals. Indeed, the way in which people target veiled Muslim women indicates that they assume that they will not react. This makes the resistance of veiled Muslim women documented in this paper all the more powerful - directly challenging the idea of the docile and oppressed female Muslim body. Participants in this study showed that they have various practices of resistance, ranging from 'active resistance' (such as verbally or physically reacting to their abusers) to ignoring their abusers, which can be seen as being the other end of a continuum.

At first sight, ignoring the abuse seems to validate the argument that veiled Muslim women are weak, passive and oppressed, which renders them 'soft' targets, especially in the eyes of the perpetrators. In contrast, 'active resistance' seems to challenge popular stereotypes of veiled Muslim women as docile, submissive and powerless. However, it could be argued that none of the participants in this study had passively accepted this victimisation. In other words, none of the participants should be perceived as passive victims; rather, deciding to ignore the abuse was a form of resistance in itself. From this perspective, coping through ignoring the abuse can be better understood as a form of agency and a choice not to engage in un-Islamic behaviour and/or as a safety mechanism for fear of the abuse escalating. Even when apparently acting passively, for example, when ignoring the abuse, veiled Muslim women are actively making choices and decisions, considering what is the best (and safest) way to deal with a specific incident of gendered Islamophobia. This infers that both active and passive forms of resistance are fluid and hence not 'immutable entities'.

Within the framework of hate crime, it could be argued that the intention of the perpetrator is to intimidate and control veiled Muslim women on the basis that they (the perpetrators) are 'superior' on multiple levels, be it religiously, culturally or racially (Perry, 2001). However, veiled Muslim women may actively resist the control that their abusers seek to exert by challenging this behaviour. By retaliating, participants sent a 'message' to their abusers; that they did not accept this behaviour and that the perpetrator had no right to verbally or physically attack them. This also sends a message to the offender's group; that gendered Islamophobia will not be tolerated by veiled Muslim women. Resistance strategies in this context convey the message to the perpetrators that victims refuse to accept their abusive behaviour. Interestingly, none of the participants who challenged their abusers were aware of the language of, or debates around, hate crime. They were simply reacting on the basis of how this abuse made them feel. Relatedly, participants who reacted in such a manner felt that this was a good way of 'letting off steam' on the basis that they dealt with the problem there and then, and did not feel that they needed to report it to the authorities. As the quotes below illustrate, reacting in this way also meant that participants felt 
less victimised by the experience because they did not internalise any feelings of anger, sadness, shame or guilt.

When they call me things like 'dirty piece of Muslim shit' I do answer back so that they shut up. That's the only way because I've left it behind and then I don't come home and think about it. Aafreen

I feel really-really good when I give the comments back because it won't get to me then. I need to answer back and then it's done, it's out of my system. Hadia

Nevertheless, a consistent theme running through all the focus group discussions was that such actions of 'active resistance' in the form of retaliation were retrospectively assessed and perceived as 'un-Islamic' by other participants. As the following dialogue illustrates, the issue of dealing with incidents of gendered Islamophobia in an aggressive manner was debated in a focus group session at a mosque.

Once I was in town [Leicester City Centre] and a guy swore at me so I turned back and I told him to 'Fuck off'. Participant A

Look, you just give Muslims a bad name by saying bad stuff to them. Participant B

No, we need to teach them we're not stupid. Participant A

You're still giving Islam a bad name because you're being violent towards them; that picture of terrorism and violence in Islam is not going to be separate for them. Participant B

Remember that the whole purpose of the veil is to not attract unwanted attention to yourself so if you're going to say something to somebody you have to try to be as polite as you possibly can. Participant $\mathrm{C}$

Similar views were put forward in the context of individual interviews with participants who were critical of veiled Muslim women who did not behave in line with the Quranic teachings. For these participants, an example of behaving 'inappropriately' in Islam, and as a result bringing shame to the Muslim community, included veiled Muslim women retaliating against their abusers. Accordingly, the following quotations illustrate these participants' 'message' to those veiled Muslim women who fail to behave as 'good' Muslims.

If you do wear it, you need to realise that you represent Islam. You can let yourself down but if you let Islam down you hurt all of us. I say 'Be careful 
of what you do when you have the veil on, be conscious of your actions'. Tashia

If you want to do something wrong, fine go ahead, but do not cover yourself Islamically, do not let your religion down, do not show your religion. When I wear the niqab I make sure I represent Islam in the best way I can. Dahab

\section{Barriers to reporting to police}

The preceding discussion shows that participants' reactions to gendered Islamophobia varied significantly, ranging from 'active resistance' (such as verbally or physically reacting) to ignoring their abusers, which can be seen as being the other end of a continuum. Although Islamophobia is recorded as a hate crime nationally, and misogyny is recorded as a hate crime locally in some police forces, it is important to note that the veiled Muslim women who took part in this study reported that they were unlikely to report their experiences to the police. This shows that on the one hand, there is a willingness to 'resist' to this victimisation but on the other hand, there is an unwillingness to report this victimisation to the police.

Indeed, the vast majority of participants did not report their victimisation experiences to the police or other official sources. Similarly, Lambert and Githens-Mazer (2010) found that the majority of hate crimes in which Muslim women wearing hijabs and niqabs had been assaulted, abused and intimidated were not reported. In the current study, a common reason for non-reporting was participants' perceptions that the police would fail to recognise the severity of this victimisation and empathise with them. Most participants were adamant that the police would fail to understand the seriousness of the case, empathise with them and accommodate their religious and cultural needs, for example, in terms of offering a female officer. The following comments help to illustrate some of the key concerns raised by participants in relation to a lack of understanding and empathy within the police service.

The police won't help us, they think we are some kind of monsters. Nabeeha

We feel that the police will not take it seriously, they don't understand women in veil anyway so how are they going to deal with this crime? They probably think we shouldn't cover our face anyway.

We feel misunderstood by the police. I've got stares from the police as well. I walked past the police and he looked at me thinking 'You are one of the terrorists', I could tell. I know that if I go to them, they're not going to give me any protection.

Focus group participants 
As these quotes show, there was a lack of confidence in the police amongst the participants. Choudhury and Fenwick (2011) point out that in cases where the police fail to take it seriously, it undermines victims' trust and confidence in the police and criminal justice system as a whole. Spalek (2006) observes that victims' satisfaction with the police response is important on the basis that police officers are the first point of contact that victims have with the criminal justice system. Indeed, the initial contact with the police is crucial because the service that victims and witnesses receive from that first contact determines their confidence in the criminal justice system and expectations of other agencies. As such, a poor experience with the police is likely to have a detrimental impact upon victims' perceptions of the wider criminal justice system, and potentially discourage them from reporting future incidents.

Furthermore, participants had little confidence in the police on the basis of either their previous negative experiences or, more commonly, their negative impressions of that agency. Correspondingly, several participants recounted past negative experiences from the police and this had led them to question the purpose of reporting their victimisation again in the future. They noted that even in cases in which the police were informed about a specific incident no arrests were made. In the context of focus group discussions, participants overwhelmingly agreed with the view that 'the police would fail to take action', as illustrated in the following quotes.

I was travelling to Birmingham by train and as I got off the station a man grabbed my niqab and pulled it off. I did report it to the police but nothing gets done.

I called the police there and then. It was in London, I got off the bus and an elderly woman pulled my veil down and the police managed to find her through CCTV camera but nothing actually happened.

We did report it to the police when we had racist abuse from our neighbours but they didn't do anything.

Focus group participants

Interestingly, the issue of whether it should be reported to the police was debated amongst participants in the context of focus group discussions. In this sense, there was a deep-seated mistrust towards the police whereas confidence in educational institutions was significantly higher based on the premise that academic research has genuine interest, and potential, in raising public awareness and influencing policy about the problem of gendered Islamophobia. These views are evident in a dialogue between participants during a focus group interview at an Islamic community centre.

I wouldn't contact the police. I don't know anybody who has contacted the police. Why should I? What can they do for us? Participant A 
But you wouldn't be here if you really believed that. Participant B

That's a different story, organisations like the University of Leicester genuinely care but the police with their reputation and their position, they become a bit high and mighty, they pretend they take their job seriously but they don't really care about us. Participant A

A core theme underpinning the findings is that participants were largely disparaging of the police. As a number of participants were keen to stress, the police was seen as a racist organisation and this was a significant barrier for reporting an Islamophobic incident to the police. Allen (2010) emphasises that a high proportion of British Muslims perceive the police to be racist. As such, this issue was cited as a common reason behind participants' views of the police as a racist organisation.

I am reluctant to go to the police, there is a lot of racism going on in the police anyway. Latifah

I feel the authorities hate Muslims; lots of Muslim brothers have been suspected of terrorism and they have been arrested and then they have been released because it was found that they weren't really guilty. Nisha

Overall, a lack of confidence in the police - whether borne from personal experience or from the reputation of that particular organisation - is quite possibly the most fundamental barrier facing victims of gendered Islamophobia, affecting nearly every aspect of accessing victim services. Finally, an additional barrier to reporting their experiences of gendered Islamophobia was the fact that participants feared insensitive questioning and hostile responses by criminal justice agents, particularly the police and the courts. Questions that suggest that victims provoked the attack by wearing the niqab can evoke feelings of guilt and self-blame that impair the victim's recovery process and discourage disclosure. Likewise, a lack of respect for veiled Muslim women's cultural and religious needs, such as failing to provide a female officer, could also cause the victim further suffering which amounts to secondary victimisation. Many participants described their experiences through the criminal justice system as frightening, intimidating and stressful.

It wasn't easy giving a statement to a male officer. It really made me understand why other sisters don't report it. Hadiqa

As victims we feel frightened and intimidated to go through the criminal justice system because we know that the veil will be a problem in court. A lot of sisters are hoping they can live their lives without ever having to contact the police about anything. Focus group participant 


\section{Informal support networks}

Throughout the interviews and focus group discussions, it became evident that participants saw the police as the only agency that they could refer to. As such, the police were seen as the 'gatekeepers' to justice. For Dunn (2007), this highlights the hegemony of the criminal justice system in the victim domain on the basis that the police are perceived as the primary provider of services to victims and witnesses of crime per se. Relatedly, there was a widespread lack of awareness amongst participants with regards to third party reporting organisations and support services. Accordingly, the majority of participants stated that they were not aware of the existence and role of other agencies, and as a result they were reluctant to report their experiences to agencies other than the police.

Participants mainly drew from informal networks of support with other Muslim women in order to cope with gendered Islamophobia. There was very little formal support, for example, from official organisations such as Victim Support; rather, it was mostly informal support from relatives and friends - people with whom participants had close ties. Specifically, talking to other veiled Muslim women about their victimisation experiences was by far the most commonly cited source of support, as can be seen in the quotations below.

There is no formal support. I just phone my friends. I tell them what happened and we talk about it. Some of them wear the veil so they do understand. Yasmine

We have to discuss it. We can't bottle these things up. Personally, I talk to my sisters [also veiled]. We compare notes kind of thing and we draw strength from the fact that we are not on our own.

We do Arabic every Tuesday [at the mosque] and we have morning coffees [gatherings for veiled Muslim women] every Wednesday. Since I've been going there for the last three years, it's like a little sister circle. That helps.

Focus group participants

Participants emphasised the importance of being able to talk through their victimisation experiences with other veiled Muslim women. In this sense, sharing their experiences was extremely useful in terms of offering mutual support and reassurance to each other. However, some participants revealed that they would not normally disclose their experiences to anyone, including family, friends or even other veiled Muslim women. They felt stigmatised by such incidents and this feeling was reinforced by being treated insensitively by their family and friends. This had resulted in this victimisation not being disclosed to anyone, as indicated in the quotations below. 
I don't tell my friends because I'm so used to it. It's not even something to talk about anymore. It happens all the time, so what? Aisha

Other veiled sisters that I know don't really talk about it. I don't tell anyone and same with everyone else I think. It's embarrassing so I just forget about it. Jamilah

It appears from the above analysis that seeking help from family and friends and being able to talk to other veiled Muslim women can be helpful. At the same time though, disclosure of victimisation can make veiled Muslim women vulnerable on the basis that they may encounter hostility, disbelief or judgmental attitudes, and this can have a harmful effect upon them to the extent of revictimising them. Correspondingly, for several participants there was little support from relatives and friends (despite often being Muslims themselves) whilst in some cases, the support was very negative. Equally worryingly, those participants who did not disclose their victimisation experiences to family and friends were less likely to report such incidents to the police or another organisation. This discussion shows that veiled Muslim women sometimes suffer in silence, concealing their experiences of abuse with no support system and nowhere to turn for help except for the Muslim God, Allah. This is epitomised by a comment made by Wadiah.

My [Muslim] family don't understand. They will just say to me 'Do not wear it then' or 'We told you so'. I don't get support from my family or friends. I get support from Him [Allah] and from knowing that what I'm doing is right. Wadiah

Such an observation chimes with the sentiments expressed by a substantial proportion of participants who found solace in their faith. This finding supports earlier research showing that Islam can act as an important support mechanism for Muslim women(Bullock, 2008; Spalek, 2002).

\section{Conclusion}

As the preceding discussion has demonstrated, veiled Muslim women are unlikely to report their experiences to the police. A common reason behind participants' reluctance to report their experiences of victimisation to the police was a belief that they would fail to take it seriously and empathise with them. Moreover, the image of the police as a racist organisation contributed to participants' reluctance to report this victimisation. Also, the fear of secondary victimisation during the investigation of the case reinforced participants' unwillingness to report their victimisation experiences. This discussion shows that official criminal justice statistics are not a reliable indicator of the extent of hate crime, which makes it difficult to assess or quantify the scale of the problem. Equally worryingly, the targeted victimisation of veiled Muslim women remains 'invisible' whilst victims do not get the support and justice they deserve; rather, they suffer in silence. 
Islamophobia is recorded as a hate crime nationally whilst Nottinghamshire Police recently became the first force in England and Wales to introduce misogyny as a separate hate crime category in order to tackle misogyny and street harassment. North Yorkshire police and Leicestershire police have followed suit, and began recording harassment of women as a hate crime. However, the effectiveness of this policy is questionable especially for marginalised groups such as veiled Muslim women who are less likely to report their experiences to the police. It is thus important to engage with veiled Muslim women, and build their confidence to come forward in order for this policy to be effective for all women. Participants in this study suggested that the police should employ strategies that will improve veiled Muslim women's confidence such as engaging with them in a religious and culturally sensitive manner, and ensuring that their voices are heard. In this context it is necessary for the police, and for service providers more generally, to receive relevant training on ways to provide high-quality services that meet the religious and cultural needs of veiled Muslim women. Moreover, it is necessary that both policy makers and criminal justice practitioners understand the diversity within the Muslim population which covers ethnicity, nationality and theology but most importantly, gender. Services need to be flexible to meet the needs of veiled Muslim women and these differ considerably from those of Muslim men who have suffered Islamophobia. As it stands, the current 'one size fits all approach' is flawed for veiled Muslim women as victims of gendered Islamophobia because it does not take into consideration the intersectionality of victims' identities, nor the fact that veiled Muslim women may be more vulnerable both online but also offline, in the 'real' world. 


\section{References}

All Party Parliamentary Group on British Muslims (2018) Report on the inquiry into A working definition of Islamophobia/anti-Muslim hatred. London: APPG.

Allen C (2010) Islamophobia. Surrey: Ashgate.

Allen C, Isakjee A and Young OO (2013) Understanding the Impact of Anti-Muslim Hate on Muslim Women. Birmingham: University of Birmingham.

Allen C and Nielsen J (2002) Summary Report on Islamophobia in the EU after 11 September 2001. Vienna: European Monitoring Centre on Racism and Xenophobia.

Bouteldja N (2011) Unveiling the Truth: Why 32 Muslim Women Wear the Full face Veil in France. London: Open Society Foundations.

Brems E (2014) Introduction to the volume. In: Brems E (ed) The Experiences of Face Veil Wearers in Europe and the Law. Cambridge: Cambridge University Press, pp. 1-17.

Bullock K and Jafri GJ (2002) Media (Mis) representations: Muslim women in the Canadian nation. Canadian Women's Studies 20(2): 35-40.

Charmaz K (2006) Constructing Grounded Theory: A Practical Guide Through Qualitative Analysis. London: Sage.

Choudhury T and Fenwick H (2011) The Impact of Counter - Terrorism Measures on Muslim Communities. Manchester: Equality and Human Rights Commission.

Cole D and Ahmadi S (2003) Perceptions and Experiences of Muslim Women who Veil on College Campuses. Journal of College Student Development 44(1): 47-66.

College of Policing (2014) Hate Crime Operational Guidance. Available at: www.report it.org.uk/files/hate_crime_operational_guidance.pdf (accessed 12 January 2018).

Crenshaw K (1989) Demarginalizing the Intersection of Race and Sex: A Black Feminist Critique of Antidiscrimination Doctrine. The University of Chicago Legal Forum 139-67.

Crenshaw K (1991) Mapping the margins: intersectionality, identity politics, and violence against women of color. Stanford Law Review 43(6): 1241-1299.

Dhamoon R K (2011) Considerations on mainstreaming intersectionality. Political Research Quarterly 64(1): 230-243.

Elgot J (2018) Boris Johnson accused of 'dog-whistle' Islamophobia over burqa comments Available at: https://www.theguardian.com/politics/2018/aug/06/borisjohnsons-burqa-remarks-fan-flames-of-islamophobia-says-mp?CMP=share_btn_tw (accessed 15 July 2018). 
Garner S and Saher S (2015) The Racialization of Muslims: Empirical Studies of Islamophobia. Critical Sociology 41(1): 9-19.

Githens-Mazer J and Lambert R (2010) Islamophobia and Anti-Muslim Hate Crime: A London Case Study. London: European Muslim Research Centre.

Glaser BG and Strauss AL (1967) The Discovery of Grounded Theory: Strategies for Qualitative Research. London: Sage.

Haddad Y (2007) The post 9/11 hijab as icon. Sociology of Religion 68(3): 252-67.

Hill Collins P (1990) Black Feminist Thought. London: Harper-Collins.

Lambert B and Githens-Mazer J (2011) Islamophobia and Anti-Muslim Hate Crime: UK Case Studies 2010 - An Introduction to a Ten Year Europe-Wide Research Project. London: European Muslim Research Centre.

Jiwani Y (2005) 'War Talk' engendering terror: Race, gender and representation in Canadian print media. International Journal of Media and Cultural Politics 1(1): 1522.

Mahmud Y and Swami V (2010) The influence of the hijab (Islamic head-cover) on perceptions of women's attractiveness and intelligence. Body Image 7(1): 90-93.

McCall L (2005) The complexity of intersectionality. Signs 30(31): 1771-1802.

Moors A (2009) The Dutch and the Face-Veil: The Politics of Discomfort. Social Anthropology 17(4): 393-408.

Moors A (2014) Face veiling in the Netherlands: public debates and women's narratives. In: Brems E (ed) The Experiences of Face Veil Wearers in Europe and the Law. Cambridge: Cambridge University Press, pp. 19-41.

Perry B (2001) In the Name of Hate: Understanding Hate Crimes. London: Routledge.

Perry B (2014) Gendered Islamophobia: hate crime against Muslim women. Social Identities 20: 74-89.

Runnymede Trust 2017. Islamophobia: still a challenge for us all. London: Runnymede Trust.

Spalek B (2006) Crime Victims, Theory, Policy and Practice. Hampshire: Palgrave Macmillan.

Unkelbach C, Forgas JP and Denson TF (2008) The turban effect: The influence of Muslim headgear and induced affect on aggressive responses in the shooter bias paradigm. Journal of Experimental Social Psychology 44(5): 1409-1413.

Unkelbach C, Goldenberg L, Müller N, Sobbe G and Spannaus N (2009) A shooter bias against people wearing Muslims headgear in Germany. International Review of Social Psychology 22(3-4): 181-201. 
Wing A and Smith M (2006) Critical race feminism lifts the veil?: Muslim women, France, and the headscarf ban. U.C. Davis Law Review 39: 743-786. 